\title{
ANALYSIS OF STUDENT DifFiculties In UNDERSTANDING The CONCEPT OF NEWTON'S LAW OF MOTION
}

\author{
Muhammad Erfan ${ }^{1)}$, Tursina Ratu ${ }^{2)}$ \\ 1) Physics Education Study Program, University of Samawa, Sumbawa Besar, Indonesia \\ E-mail: erfan.fisika@fkipuniversitassamawa.ac.id \\ 2) Physics Education Study Program, University of Samawa, Sumbawa Besar, Indonesia \\ E-mail: tursinaratu.fisika@fkipuniversitassamawa.ac.id
}

\begin{abstract}
The aim of this study is to investigate the difficulties experienced by students on the concept of Newton's Law of Motion. The method used is descriptive analysis with a sample of 14 students who take Mechanics Course on Physics Education Study Porgram, Faculty of Teacher Training and Education of Samawa University. The data was collected by essai test. Based on the test result show that (1) students have difficulty in integrating mathematical equation. (2) students was unable to operated integration and differentiation related to trigonometric function. (3) students have not understood the concept of potential in conservative force field.
\end{abstract}

Keywords: Difficulties of Learning; Physics Concept; Newton's Law of Motion

\section{INTRODUCTION}

In every process of learning, both educators and learners always expect that the learning objectives can be achieved. Included in lectures process, lecturers and students always expect that the goals of the lecture can be achieved well. The objectives of the lectures that have been compiled are to consider several things such as the learning outcomes of graduates referring to the Indonesian National Qualification Framework (KKNI) and the competency of the courses that support the achievement of the study program.

Classical Mechanics is an important subject for students of physics education program considering that the lecture material is widely contained in the curriculum of physics subjects taught at the secondary school level. Therefore, the student have to master the appropriate concepts of mechanics as a provision in delivering the teaching material in secondary schools.

Many things that happen during classical mechanics lectures that are sometimes not realized before. For example, educators or lecturers sometimes has done maximum effort lecturing in the classroom. All the abilities and knowledge relating to Newton's Law concepts of motion were taught to students in order students can achieve the learning objectives. But the achievement of learning outcomes obtained by students in Newton's Law of motion is not well expected.

Newton's law of motion is one of the basic concepts that must be mastered by students as physics teacher candidates.
The study of motion in physics has been done since the time of Greece which is further explained and more in detail by Newton. Anything that related to motion must have involve the Newton's law of motion.

Some research results show that students find it difficult to understand the basic concepts of physics such as the concept of force, acceleration, displacement, acceleration of gravity and so on [1] [2] [3] [4] [5]. The difficulty in understanding Newton's Law concepts of motion is not only experienced by students at secondary level but also students of physics teacher candidates [6] [7]. This indicates that the students and physics teacher candidates need to deepen their understanding the basic concept of Newtonian Mechanics.

The test results about Newton's law of motion show that many students have not achieved the learning outcomes as they should. Allegedly, students might have difficulties in understanding the concept of Newton's law of motion, causing difficulties in solving problems related to Newton's law of motion.

The difficulty of students in solving problems related to Newton's law of motion must be identified as soon as possible. The identification of the difficulties of the students are intended so that these difficulties are immediately recognized and can be overcome through various methods and strategies in classroom teaching and learning. Therefore, in this research will be focused on identifying the difficulties of students in understanding the concept of Newton's Law of motion such as 


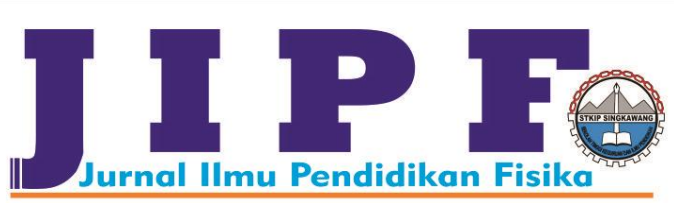

displacement, speed, acceleration, and force causing it's motion.

The concept is the idea of a person or group of people expressed in the definition as knowledge products include principles, laws and theories. Concepts can be derived from facts, events, experiences, through generalizations and abstract thinking [8]. The concept as an abstraction of an event, object, or phenomenon that has similar characteristics or signs. Further, Bruner, Goodnow, and Austin state that a concept has five important elements: (1) Name, (2) Definition, (3) Symbol or Attribute, (4) Value, and (5) Example [9]. In physics, we can found the concept of electrons, protons, neutrons, waves, solids, and of course about the motion.

As the development of science and the discovery of new facts about physics concept, a concept can be changed or renewed. In the physics concept sometimes we encountered one concept of physics has interconnection with other physics concepts, for example the concept of motion can not be separated from the concept of force and the concept of energy that causes the motion.

Cari state that the causes of a person having difficulty in understanding concepts are mistakes in representing languages such as (1) math languages, (2) intuitive language, (3) communication languages, (4) language definitions, and (5) language of communication. Other difficulties encountered include difficulty in connecting the previous concepts to the concepts in present learning, errors and inaccuracies in calculations, errors in defining magnitudes, and errors in interpreting symbols or attributes [10].

There are a strong relationship between students mathematical skils and mastering the physics concepts, its give a significant influence on the achievement of physics learning outcomes [11] [12]. Many studies show that there are a positive correlation between the value of physics in college with the pretest value of math skills at or before the lecture [13]. In addition, many physics problems in the solution using mathematical concepts. For example, the concept of trigonometry is widely used in dynamics or statics of mechanics.

Newton's first law of motion states that "An object remains at stationary or moves at a fixed rate speed along a straight line, unless it is given a total non-zero force" [14]. Mathematically given by:

$$
\sum F=0
$$

The tendency of an object to maintain a stationary state or fixed motion in a straight line is called inertia. Therefore, Newton's First Law is sometimes referred to as the law of inertia.

An example that can be explained in everyday life from Newton's first law of motion is the inertia we experience while sitting in a speeding bus, then the bus driver suddenly stepped on the brake pedal. At that time the bus passengers feel pushed forward in the direction of the bus movement.

Newton's second law of motion can be explained by illustrating the presence of an external force $\mathbf{F}$ acting on a particle of mass $m$ which as a consequences the particle moving at velocity $\mathbf{v}$ [7]. It can be said that Newton's Second
Law states that forces acting on an object are equal to changes in linear momentum (p) over time (t). In mathematical expression can be written:

$$
\vec{F}=\frac{d \vec{p}}{d t}=\frac{d(m \vec{v})}{d t}=m \cdot \frac{d \vec{v}}{d t}+\vec{v} \cdot \frac{d m}{d t}
$$

If the mass of the object (m) does not change over time or the mass is constant and the moving speed of the object does not approach the speed of light, equation (2) become into:

$$
\vec{F}=m \cdot \frac{d \vec{v}}{d t}
$$

Because the change of velocity over time is acceleration of the object, therefore:

$$
\vec{F}=m \cdot \vec{a}
$$

Newton's third law state that "when an object gives force to a second object, the second object gives the same force as opposite to the first one" [14]. The action force and reaction force work on different objects. Mathematically given by the equation:

$$
\vec{F}_{\text {aksi }}=-\vec{F}_{\text {reaksi }}
$$

The application of Newton's third law in everyday life is when someone fires a bullet with a shotgun. The great force that rifles are given on the bullet is equal to the magnitude of force given by bullets on the rifle and sometime the shooter felt knock back. This phenomena is called recoil. Another example of the Newton's third law of motion is the rocket launch. The rocket gives a large force on the gas, and the gas gives the same force but in opposite direction to the rocket so this force causes the rocket out of the earth gravitational field and into the space [14].

\section{METHODS}

This analytical descriptive research was to describe the difficulties experienced by students in understanding the concept of Newton's law of motion. The subjects of this research consist of 14 students $2^{\text {nd }}$ semester who take the Mechanics Course at Physics Education Study Program, Faculty of Teacher Training and Education, University of Samawa.

TABLE I

The CONCEPT OF NEWTON's LAW OF MOTION ON EACH QUESTIONS

\begin{tabular}{cl}
\hline $\begin{array}{c}\text { Question } \\
\text { number }\end{array}$ & \multicolumn{1}{c}{ The concept that has to be mastered } \\
\hline 1 & $\begin{array}{l}\text { Velocity, Acceleration, and Force including } \\
\text { Newton second law of motion. } \\
\text { Position of an object, displacement, velocity and } \\
\text { force at any time } t\end{array}$ \\
3 & $\begin{array}{l}\text { Force in terms of time } t \text {, position, velocity of a } \\
\text { particle in circular motion, and the concept of } \\
\text { trigonometry. } \\
\text { The contant of the equation of the force in order } \\
\text { the force is conservative force field. } \\
\text { The cross product of a vector and conservative } \\
\text { force field }\end{array}$ \\
\hline
\end{tabular}




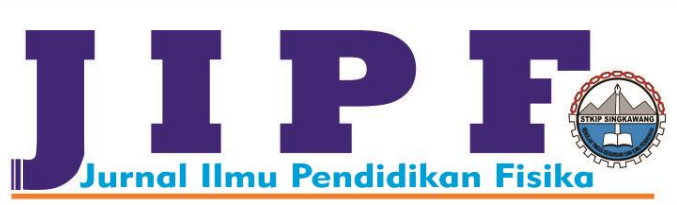

Data collection using a test instrument in the form of a essay test consisting of five questions. Each of the essay test measures the concepts that has mastered by the student or the candidate of physics teacher. The essay test was more emphasized in Newton's second Law of motion. Each question measures the concepts that has to be mastered by students as described in table 1. Research data was analyzed in order to identify the difficulties experienced by students.

\section{RESULT AND DISCUSSION}

After the test was conducted on 14 physics teacher candidates related to Newton's Law on Motion, an average score of 48.3 was obtained. Maximum score achieved by students was 80 and the minimum was 20 . These results is in low category or in other words, there are still many difficulties and errors related to Newton's Law on Motion. It is necessary to investigate the difficulties of students in solving problems related to Newton's Law of Motion. In general the student's mistake in understanding Newton's Law of Motion concept is presented in table 2 .

TABEL II

RECAPITULATION OF STUDENT COMPETENCY ON THE CONCEPT OF NEWTON'S LAW OF MOTION

\begin{tabular}{|c|c|c|}
\hline No & $\begin{array}{c}\text { Competence to be achieved by } \\
\text { the Students }\end{array}$ & $\begin{array}{c}\text { Percent of Wrong } \\
\text { Answers (\%) } \\
\end{array}$ \\
\hline \multirow[t]{2}{*}{1} & $\begin{array}{l}\text { a. Determine a constant force to } \\
\text { accelerate particles with its } \\
\text { mass, the initial velocity and } \\
\text { the final velocity of the } \\
\text { particle are known. }\end{array}$ & 0 \\
\hline & $\begin{array}{l}\text { b. Determine the magnitude of } \\
\text { the force in problem 1a. }\end{array}$ & 0 \\
\hline \multirow[t]{2}{*}{2} & $\begin{array}{l}\text { a. Determine the position by the } \\
\text { Initial force and initial vector } \\
\text { position are known }\end{array}$ & 78 \\
\hline & $\begin{array}{l}\text { b. Determine the velocity of the } \\
\text { particle at any later time }\end{array}$ & 71 \\
\hline \multirow[t]{2}{*}{3} & $\begin{array}{l}\text { a. Determine the position vector } \\
\text { of the moving particles if the } \\
\text { force field and the initial } \\
\text { position are known }\end{array}$ & 100 \\
\hline & $\begin{array}{l}\text { b. Determine the velocity of the } \\
\text { particle at any later time }\end{array}$ & 100 \\
\hline \multirow[t]{2}{*}{4} & $\begin{array}{l}\text { a. Determine the constant in the } \\
\text { equation of conservative } \\
\text { force field. }\end{array}$ & 21 \\
\hline & $\begin{array}{l}\text { b. Determine the potential on } \\
\text { the conservative force field }\end{array}$ & 92 \\
\hline 5 & $\begin{array}{l}\text { Evaluating wether the equation } \\
\text { of force field given are } \\
\text { conservative force field or not. }\end{array}$ & 28 \\
\hline
\end{tabular}

Based on the recapitulation of student achievement on the concept of Newton's law of motion, the difficulties experienced by students related to Newton's Law of Motion are as follows.

First, students experienced difficulty in integrating mathematical equations. After the answers of physics teacher candidates are examined one by one, there are still many mistakes in integrating mathematical equations in problem number 2. Problem number 2 is as follows.

A particle of unit mass moves in a force field given in term of time t by $\vec{F}=(6 t-8) \hat{i}-60 t^{3} \hat{j}+\left(20 t^{3}+36 t^{2}\right) \hat{k}$. Its initial position and velocity are given respectively by $\hat{r}_{0}=2 \hat{i}-3 \hat{k}$ and $\hat{v}_{0}=5 \hat{i}+4 \hat{j}$. Find the (a) position and $(b)$ velocity of the particle at $t=2$.

In Students answer sheets to question 2, only 3 students worked on the problem (b) first, and they did the problem (a), it is not a problem considering that to obtain the position vector of particle it must integrate the equation of the velocity of particle. To obtain the velocity equation, it must have to $\vec{F} / m$

integrate the equation $/ m$, then integrate the result again to obtain the equation of position of the particle.

Of the 14 students, only 3 answered correctly about number 2 both points (a) and points (b). The main mistake of 11 others were incorrectly integrate the equation there are 5 students and 6 students are less conscientious in involving the initial velocity constants and initial position vector so that the calculation of position and particle velocity at the time were not match with the answer key.

Second, Students of $2^{\text {nd }}$ semester who take the Mechanics Course at Physics Education Study Program, Faculty of Teacher Training and Education, University of Samawa have not mastered integral or differential operation involving trigonometry. This are based on the answer of the student worked the problem number 3 as follows.

The force acting on a particle of mass $m$ is given in terms of time $t$ by $\vec{F}=(a \cos \omega t) \hat{i}+(b \sin \omega t) \hat{j}$. If the particle is initially at rest at the origin, find its (a) position and (b) velocity at any later time.

From the question number 3 , although there are 5 students who tried to answer but none of them answered correctly, after further questioning, all students still have not mastered and still unable to integrate mathematical equations involving the concept of trigonometry.

The concept of trigonometry is a basic mathematical skill that must be mastered by students in studying physics. If the student has not been able to master the concept of trigonometry while the concept is a very important basic capability, then it is certain that the student will have difficulty in understanding Newton's Law of motion related to the motion equations denoted in trigonometric equations.

Third, Almost all of students have not understood the potential of conservative force field. This was based on the answer of the student in number 4 as follows.

(a) Find constant $a, b, c$ so that the force field defined by $\vec{F}=(x+2 y+a z) \hat{i}+(b x-3 y-z) \hat{j}+(4 x+c y+2 z) \hat{k}$ conservative force field. (b) What is the potential associated with the force field in $(a)$ ?

In answering the question number 4 part (a), most of students have answered correctly. But for the part (b), there is 


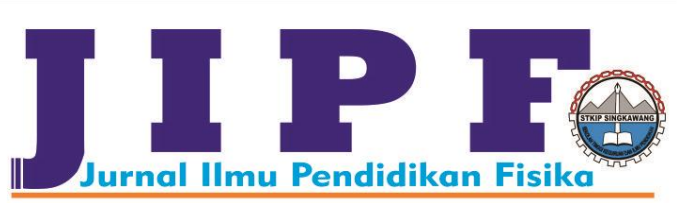

only one person attempt to answer with the right step but the answer is still wrong value. Of the 14 students, 13 of them were totally in blank answer because they did not yet understand the relation between the conservative-force field and the potential.

In order to obtain the potential, it is necessary to integrate the force field first, from the equations of force field we obtained $\quad \vec{F}_{1}=(x+2 y+a z) \quad, \quad \vec{F}_{2}=(b x-3 y-z)$, $\vec{F}_{3}=(4 x+c y+2 z)$ and since the vector differential $\nabla=\frac{\partial}{\partial x} \hat{i}+\frac{\partial}{\partial y} \hat{j}+\frac{\partial}{\partial z} \hat{k}$ $\partial z$, the potential is obtained by $V=-\int \vec{F}_{1} d x-\int \vec{F}_{2} d y-\int \vec{F}_{3} d z$. In integrating the equations of force field to be the potential, partial integrals are required. The $2^{\text {nd }}$ semester Students who take the Mechanics Course at Physics Education Study Program, Faculty of Teacher Training and Education, University of Samawa have not mastered the partial integration operation yet.

\section{CONCLUSION}

Based on the discussion, it can be concluded some findings related to student difficulties in understanding the concept of Newton's Law of Motion. First, students experienced difficulty in integrating mathematical equations. Secondly, Students have not mastered integral or differential operation involving trigonometry. Thirdly, almost all of $2^{\text {nd }}$ semester students who took the Mechanics Course at Physics Education Study Program, Faculty of Teacher Training and Education, University of Samawa have not understood the potential of conservative force field.

\section{REFERENCES}

[1] Bayraktar, S. 2006. Turkish pre-service teachers'misconceptions about force and motion. International Science Education Conference, Singapore.

[2] Clement, J. 1982. Students' preconceptions in introductory mechanics. American Journal of Physics, 50(1): 66-72.

[3] Legendre, M.F. 1997. Task analysis and validationfor a qualitative, exploratory curriculum in force and motion. Instructional Science, 25(1): 255-305.

[4] Osborne, R.J. and Wittrock, M.C. 1983. Learning science: A generative process. Science Education, 67(4): 489-508.

[5] Rosdianto, H. 2017. Pengaruh Model Generative Learning Terhadap Hasil Belajar Ranah Kognitif Siswa Pada Materi Hukum Newton. Jurnal Pendidikan Fisika dan Keilmuan (JPFK), 3(2): 66-69

[6] Bayraktar, S. 2009. Misconceptions of Turkish PreService Teachers about Force and Motion. International Journal of Science and Mathematics Education, 7(1): 273-291.

[7] Spiegel, Murray R. 1967. Schaum's Outline of Theory and Problems of Theoretical Mechanics with an introduction to Lagrange's Equations and Hamiltonian
Jurnal Ilmu Pendidikan Fisika

Volume 3 Number 1 month March 2018. Page 1-4 p-ISSN: 2477-5959 e-ISSN: 2477-845I

Theory. New York: McGRAW-HILL BOOK COMPANY.

[8] Gunawan, dkk. 2008. Model Pembelajaran Berbasis Multimedia Interaktif untuk Meningkatkan Penguasaan Konsep Calon Guru pada Materi Elastisitas. Jurnal Penelitian Pendidikan IPA, 2(1): 11-22.

[9] Chiappetta, E. L \& Koballa, T. R. 2010. Science Instruction in the Middle and Secondary Schools. New York: Allyn \& Bacon.

[10] Handhika, J \& Kurniadi E. 2014. Analisis Kesulitan Mahasiswa dalam Memahami konsep Vektor Gaya pada Hukum Newton. JURNAL LPPM, 2(1): 47-51.

[11] Rosdianto, H., \& Toifur, M. (2017). Implementasi Teori Distribusi Probabilitas Gaussian Pada Kualitas Rangkaian Penyearah Gelombang Penuh. SPEKTRA. Jurnal Fisika dan Aplikasinya, 2(1), 83-90.

[12] Rosdianto, H. (2017). Penentuan Percepatan Gravitasi Pada Percobaan Gerak Jatuh Bebas Dengan Memanfaatkan Rangkaian Relai. SPEKTRA: Jurnal Fisika dan Aplikasinya, 2(2), 107-112.

[13] Meltzer, David E. 2002. The relationship between mathematics preparation and conceptual learning gains in physics: A possible "hidden variable" in diagnostic pretest scores. American Journal of Physics, 70(12): 1259-1268.

[14] Giancoli, Douglas C. 2011. Fisika (terjemahan Yuhilza Hanum). Jakarta: Erlangga. 